$\begin{array}{r}\begin{array}{c}\text { Interdyscyplinarne Konteksty Pedagogiki Specjalnej } \\ \text { NUMER 21/2018 }\end{array} \\ \text { BEATA BOROWSKA-BESZTA } \\ \text { Uniwersytet Mikołaja Kopernika w Toruniu } \\ \hline\end{array}$

\title{
Ohyake (公) czy watakushi (私) i puraibashii (プライバシー)? Przestrzenie i artefakty systemu edukacji specjalnej i inkluzyjnej w Japonii: Raport z wizualnej mikroetnografii edukacyjnej
}

ABSTRACT: Beata Borowska-Beszta, Ohyake (公) czy watakushi (私) i puraibashii (プライ バシー)? Przestrzenie $i$ artefakty systemu edukacji specjalnej $i$ inkluzyjnej w Japonii: Raport z wizualnej mikroetnografii edukacyjnej [Ohyake (公) czy watakushi (私) i puraibashii (プライバシー)? Space and Artifacts of Special Education and Inclusive Education Facilities in Japan: Report on Visual Educational Microethnography]. Interdyscyplinarne Konteksty Pedagogiki Specjalnej, nr 21, Poznań 2018. Pp. 31-65. Adam Mickiewicz University Press. ISSN 2300-391X. DOI: https:// doi.org/10.14746/ikps.2018.21.03

The presented research is a microethnographic report from a visual ethnography undertaken in May 2016, in 6 Japanese schools and 1 adult support center with disabilities located on island Kyushu in Fukuoka Prefecture. The study deals with a issues of the educational material culture and refers to the study of space and school artifacts designed in schools for students with special educational needs understood as intellectual disabilities and for adults with such potential as well. The research was grounded in E. Schein's organizational culture, furthermore on the concept of private space and public space described by T. Tamura and my author's concept developed at the reinterreted role of the handicapped human in stationary institution published by W. Wolfensberger's (1969).

KEY WORDS: Japan research, cultural research, disability studies, special education, inclusive education, ethnographic research, visual research, microethnography 


\section{Wprowadzenie}

Japonia jest interesującą poznawczo kulturą Azji wschodniej i obszarem badań terenowych, o czym mogłam się przekonać w maju 2016 r. podczas stażu naukowo-badawczego na wyspie Kiusiu w Fukuoce. Autorzy Makoto Nakada i Takanori Tamura sformułowali myśl o tym, że "Japonia jest skomplikowanym krajem - nawet dla Japończyków!"1. Badacze zauważają, że jeśli Japonia jest skomplikowana dla Japończyków, to o ile bardziej jest skomplikowana obcokrajowców i badaczy z zagranicy? Zgadzam się z tą obserwacją. Staż, pobyt w Japonii wymagał ode mnie wzmożonej uwagi, nieustannej czujności $\mathrm{w}$ reakcjach na sytuacje społeczne. Ponadto aktywności i otwartości na subtelne i zrytualizowane formy kontaktów służbowych oraz działań naukowo-badawczych w terenie.

Poniższy raport $\mathrm{z}$ badań terenowych, opartych na mikroetnografii wizualnej i prowadzonych zagranicą w maju 2016 r., stanowi część badań edukacyjnych kultur organizacyjnych szkolnictwa w Japonii, jakie prowadziłam na wyspie Kiusiu w mieście Fukuoka. Celem części badań, analizowanej niniejszym w raporcie, było zrozumienie i przeanalizowanie przestrzeni i wybranych artefaktów behawioralnych i fizyczno-materialnych sześciu szkół i jednej placówki wsparcia dorosłych z niepełnosprawnością intelektualną, w kontekstach kultury organizacyjnej, emicznego, japońskiego rozumienia przestrzeni oraz przestrzeni jako kulturowego rezerwuaru kodowania konstruktu niepełnosprawności. Praca analityczna została oparta koncepcjach kultury organizacyjnej Edgara Scheina ${ }^{2}$ koncepcji przestrzeni publicznej - ohyake (公) i prywatnej nazwanej - watakushi (私) i puraibashii (プライバシー) w opracowaniu Takanoriego Tamury ${ }^{3}$ oraz na

${ }^{1}$ M. Nakada, T. Tamura, Japanese Conceptions of Privacy: An Intercultural Perspective, "Ethics and Information Technology" 2005, March, 7/ 1, s. 31.

2 E. Schein, Organizational Culture and Leadership, Jossey-Bass, San Francisco 2010.

3 T. Tamura, Japanese feelings for privacy MANUSYA, "Journal of Humanities" (Special Issue No. 8, 2004) s. 138-156 http://www.manusya.journals.chula.ac.th/ files/essay/Tamura_p121-139.pdf [dostęp: 4.07.2017]. 
mojej koncepcji przestrzeni jako rezerwuarze kulturowego kodowania konstruktu niepetnosprawności, zbudowanej na rozwiniętej i reinterpretowanej koncepcji roli człowieka upośledzonego w instytucji stacjonarnej, autorstwa Wolfa Wolfensbergera 4 . Badania prowadzone były w ramach współpracy naukowej (od 2011 nieformalnej, a od 2013 r. formalnej) z profesorem pedagogiki porównawczej Noritomo Tasaki z Uniwersytetu Żeńskiego Kiusiu (Kyushu Women's University) oraz Uniwersytetu Edukacji Nauczycieli w Fukuoce (University of Teacher Education in Fukuoka) w Japonii. Profesor N. Tasaki był w Polsce gościem seminariów naukowych zorganizowanych na Wydziale Nauk Pedagogicznych UMK 11 września 2013 r. oraz 10 kwietnia 2017 r. W niniejszym raporcie nie omawiam instytucjonalnych i teoretycznych założeń japońskiego systemu edukacji specjalnej oraz inkluzyjnej. Temu poświęcę odrębną publikację.

\section{Ramy teoretyczne projektu badawczego}

Poniższy raport ilustruje główne wyniki mikroetnografii wizualnej i stanowi wycinek szerszych badań terenowych, etnograficznych poświęconych: japońskim studiom nad niepełnosprawnością, koncepcjom niepełnoprawności w Japonii oraz systemowi edukacji specjalnej i inkluzyjnej w tym kraju. Referowany w artykule raport $\mathrm{z}$ badań jakościowych jest $\mathrm{w}$ sensie metodologicznym zarówno edukacyjną etnografią instytucjonalną, jak również wizualną mikroetnografią. Jednym z celów badawczych projektu badań etnograficznych w ramach stażu naukowego i badań terenowych było poznanie, przeanalizowanie oraz opisanie przestrzeni i artefaktów systemu edukacji specjalnej oraz inkluzyjnej dla dzieci, młodzieży z niepełnosprawnością intelektualną, zwanych - chiteki shōgai (知的障害)

${ }^{4} \mathrm{~W}$. Wolfensberger, The Origin And Nature Of Our Institutional Models, [w:] Changing Patterns in Residential Services for the Mentally Retarded, President's Committee on Mental Retardation, Washington, D.C. January 1969, http:/ / www.disabi litymuseum.org/dhm/lib/detail.html?id=1909\&page=all [dostęp: 4.07.2017]. 
i/lub zaburzeniami rozwoju, zwanych - hattatsu shōgai (発達障害). $\mathrm{W}$ trakcie gromadzenia danych $\mathrm{w}$ terenie okazało się, iż myślenie o japońskich przestrzeniach i artefaktach edukacyjnych (behawioralnych i fizycznych) oraz ich rozumienie przez Japończyków, są związane nierozerwalnie $\mathrm{z}$ normami i wartościami, dlatego też postanowiłam analizować artefakty z perspektywy fenomenów, które osadzone są na kontinuum symboli oznaczających kulturowo to, co publiczne oraz to, co prywatne. Przestrzenie materialne systemu edukacji oraz artefakty są zatem analizowane $\mathrm{w}$ kontekście kultur organizacyjnych, a także przestrzeni jako kulturowego rezerwuaru kodowania konstruktu niepełnosprawności. Główne pytanie badawcze, które postawiłam do tej części projektu brzmi:

Jakie sa przestrzenie, artefakty oraz nadawane im kulturowe znaczenia w kulturach organizacyjnych systemu edukacji specjalnej i inkluzyjnej w Japonii?

Poniższe badania kultur organizacyjnych zarówno w sensie ontologicznym, epistemologicznym i aksjologicznym, zostały oparte na koncepcjach teoretycznych i metodologicznych antropologów kultury m.in. Jamesa P. Spradleya ${ }^{5}$, Edwarda Thitchella Halla ${ }^{6}$, Harrego F. Wolcotta ${ }^{7}$, Martyna Hammersleya, Paula Atkinsona ${ }^{8}$, Martyna Hammersleya ${ }^{9-10}$, NormanaDenzina i Yvonny Lincoln ${ }^{11}$,

${ }^{5}$ J. Spradley, The Ethnographic interview, Holt, Rinehart \& Winston, New York 1979. J. Spradley, Participant observation, Holt, Rinehart \& Winston, New York 1980.

${ }^{6}$ E. Hall, Ukryty wymiar, Muza, Warszawa 1997.

${ }^{7}$ H.F. Wolcott, Posturing in qualitative inquiry, [w:] The Handbook of Qualitative Research in Education, red. M.D. LeCompte, WL Millroy \& J. Preissle, Academic Press, NewYork 1992, s. 3-52.

8 M. Hammersley, P. Atkinson, Metody badań terenowych, Zysk i S-ka, Poznań 2000.

${ }^{9} \mathrm{M}$. Hammersley, Teaching qualitative methodology: craft, profession or bricolage, [w:] Qualitative Research Practice, red. C. Seale, G. Gobo, J.F. Gubrium, D. Silverman, Thousand Oaks, Sage 2004, s. 549-560.

${ }^{10}$ Educational Research and Evidence-based Practice, red. M. Hammersley, In association with the Open University, Sage, London 2007.

11 N. Denzin, Y. Lincoln, Metody badań jakościowych, T. 1, 2, PWN, Warszawa 2009. 
Michaela Angrosino12, Judit Lee Green i Davida Bloome13, Sarah Pink14, Marcusa Banksa15, Dariusza Jemielniaka16. Ponadto psychologa Johna W. Creswella ${ }^{17}$, socjologów Wolfa Wolfensbergera18, Takanori Tamury ${ }^{19}$ oraz badaczy z obszaru nauk o zarządzaniu Edgara Scheina ${ }^{20}$, Bogusława Wierneka ${ }^{21}$, Moniki Kostery 22 oraz pedagogów: Ireneusza Kaweckiego23, Aleksandra Nalaskowskiego ${ }^{24}$, Beaty Borowskiej-Beszty25, Dariusza Kubinow-

12 M. Angrosino, Badania etnograficzne i obserwacje, PWN, Warszawa 2010.

13 J.L. Green, D. Bloome, Ethnography and ethnographers of and in education: a situated perspective, [w:] Handbook for literacy educators: research in the community and visual arts, red. J. Flood, S.B. Heaths, D. Lapp, Macmillan, New York 1997, s. 181-202.

14 S. Pink, Etnografia wizualna. Obrazy, media i przedstawienie w badaniach, UJ, Kraków 2008.

${ }^{15}$ M. Banks, Materiały wizualne w badaniach jakościowych, Niezbędnik Badacza, PWN, Warszawa 2009.

16 D. Jemielniak, Badania jakościowe, Metody i narzędzia. T.2. PWN, Warszawa 2012.

D. Jemielniak, Badania jakościowe, Podejścia i teorie. T. 1. PWN, Warszawa 2012.

${ }^{17}$ J. Creswell, J., Research Design: Qualitative, Quantitative, and Mixed Methods Approaches. 3rd Edition. Sage Publications, Inc, Los Angeles 2009.

$18 \mathrm{~W}$. Wolfensberger, op. cit.

19 T. Tamura, Japanese feelings for privacy MANUSYA, "Journal of Humanities" (Special Issue No.8 2004) s. 138-156 http:/ / www.manusya.journals.chula.ac.th/files/ essay/Tamura_p121-139.pdf (dostęp: 4.07.2017).

${ }^{20}$ E. Schein, Organizational Culture and Leadership, Jossey-Bass, San Francisco 2010.

${ }^{21}$ B.Wiernek, Kultura organizacyjna przedsiębiorstwa, Oficyna Wydawnicza TEXT, Kraków 2000.

${ }^{22}$ M. Kostera, Antropologia organizacji, Metodologia badań terenowych, PWN, Warszawa 2003.

${ }^{23}$ I. Kawecki, Dane wizualne w badaniach pedagogicznych, "Pedagogika Kultury" 2009, t. 5

${ }^{24}$ A. Nalaskowski, Przestrzenie i miejsca szkoły, Oficyna Wydawnicza „Impuls”, Kraków 2000.

${ }^{25}$ B. Borowska-Beszta, Pracownicy Fundacji (metoda etnograficzna), [w:] Formowanie się wspólnoty $w$ Fundacji im. Brata Alberta w Radwanowicach, Wydawnictwo i Drukarnia Towarzystwa Słowaków w Polsce, Kraków 2001, s. 260-322; eadem, Etnografia dla terapeutów (pedagogów specjalnych) - szkice metodologiczne, Oficyna Wydawnicza "Impuls”, Kraków 2005; eadem, Anatema(?) szoku kulturowego w andragogice specjalnej, „Edukacja Otwarta” 2008, nr 2, s. 163-179; eadem, Etnografia stylu życia kultury dorostych torunian z zaburzeniami rozwoju. UMK, Torun 2013. 
skiego ${ }^{26}$, Justyny Nowotniak27, Elżbiety Siarkiewicz, Ewy Trębińskiej-Szumigraj, Darii Zielińskiej-Pękał28.

\section{Przegląd literatury}

Ramy teoretyczne projektu jakościowego zostały oparte na założeniu M. Kostery ${ }^{29}$ o tym, że organizacja jest kultura, co oznaczło postrzeganie elementów systemu edukacji japońskiej jako kultur organizacyjnych. Ponadto $\mathrm{w}$ sensie ontologicznym badania $\mathrm{w}$ niniejszym raporcie $z$ badań oparte zostały na uprzednio wspomnianej triadzie koncepcji dotyczących modelu kultury i artefaktów materialno-fizycznych autorstwa E. Scheina ${ }^{30}$, koncepcji przestrzeni T. Tamury ${ }^{31}$ oraz mojej autorskiej koncepcji przestrzeni jako rezrwuaru kulturowego kodowania konstruktu niepetnosprawności zbudowanej na koncepcji ról człowieka upośledzonego $\mathrm{w}$ instytucjach stacjonarnych $W$. Wolfensbergera ${ }^{32}$. Szczegółowe analizy badanych scen kulturowych i artefaktów w Japonii prowadziłam zatem:

Po pierwsze, w kontekście odwróconego piramidowego modelu kultury organizacyjnej E. Scheina ${ }^{33}$, wskazującego w modelu kultury: artefakty, wartości i ukryte założenia, odniesione do wiedzy ukrytej (tacit). E. Schein wskazuje, że do zrozumienia kultury organizacji potrzebna jest analiza widzialnych artefaktów, czyli „skonstruowanego środowiska organizacji, jej architektury, technologii,

${ }^{26}$ D. Kubinowski, Jakościowe badania pedagogiczne. Filozofia - Metodyka - Ewaluacja, UMCS, Lublin 2010.

${ }^{27}$ J. Nowotniak, Społeczne światy pokoi nauczycielskich, „Teraźniejszość - Człowiek - Edukacja: kwartalnik myśli społeczno-pedagogicznej", nr 3(55), s. 71-86

${ }^{28}$ E. Siarkiewicz, E. Trębińska-Szumigraj, D. Zielińska-Pękał, Edukacyjne prowokacje. Wykorzystanie etnografii performatywnej w procesie kształcenia doradców, Oficyna Wydawnicza „Impuls”, Kraków 2012.

${ }^{29}$ M. Kostera, Antropologia organizacji, Metodologia badań terenowych, PWN, Warszawa 2003.

${ }^{30}$ E. Schein, Organizational Culture and Leadership, Jossey-Bass, San Francisco 2010.

${ }^{31} \mathrm{~T}$. Tamura, op. cit.

$32 \mathrm{~W}$. Wolfensberger, op. cit.

${ }^{33}$ E. Schein, op. cit. 
układu biur, noszonych ubiorów, obserwowalnych i słyszalnych wzorów zachowań, oraz oficjalnych dokumentów takich jak: statuty, różne materiały informacyjne dla pracowników, historie" 34 . E. Schein nazywa kulturę organizacyjną zespołem sensownych reguł postępowania, odkrytych, ustanowionych i rozwiniętych przez grupę, służących do radzenia sobie $z$ problemem integracji i zewnętrznym dostosowaniem, które dzięki dobremu działaniu wytaczają nowym członkom sposób myślenia i odczuwania w aspekcie wspomnianych problemów ${ }^{35}$.

Po drugie, badania ugruntowałam w japońskiej koncepcji przestrzeni według T. Tamury, dzielącej przestrzeń i artefakty kulturowe na to, co jest publiczne i nazwane - ohyake (公) i to, co jest prywatne - i zwane watakushi (私) oraz puraibashii (プライバシー). O japońskiej koncepcji przestrzeni T. Tamura ${ }^{36}$ pisze następująco: watakushi (私) jest chronologicznie starszym słowem niż puraibashii (プライバシー) na określenie symboliczne w Japonii tego, co jest prywatne (częściowe, sekretne, indywidualne lub czasem postrzegane jako samolubne). Sprawy i problemy oznaczone przez Japończyków symbolem lingwistycznym watakushi i puraibashii są mniej ważne i wartościowe dla Japończyków niż sprawy oznaczone przestrzenią publiczną ohyake (公). Zdaniem autora Japończycy używają współcześnie ohyake (公), watakushi (私) oraz puraibashii (プライバシー) jako ekwiwalentów na doprecyzowanie $\mathrm{w}$ przestrzeni oraz oznaczenie wartości tego, co jest publiczne oraz tego, co jest dla nich prywatne. T. Tamura ${ }^{37}$ kontynuuje rozważania i mówi, że etymologia słowa ohyake (公) = "oh" oznacza: wielki, a "yake” oznacza: dom, dlatego też ohyake (公) stosuje się na oznaczenie "wielkiego domu” (czyli dworu cesarskiego, cesarskiego domu, rządu, narodu i społeczeństwa). Ohyake (公) oznacza również rzeczy, które są „otwarte” oraz postawę „bycia bezstronnym”. T. Tamura uważa, że "to co publiczne" i "rząd” oznaczają prawie to

\footnotetext{
34 Ibidem, s. 62.

35 E. Schein, op. cit.

36 T. Tamura, op. cit.

37 Ibidem.
} 
samo $^{38}$. Zarysowany powyżej teoretycznie podział przestrzeni w Japonii był początkowo dla mnie, badaczki Europejki, czytelny, jednakże w praktyce gromadzenia danych ujawniły się niuanse kulturowe dotyczące subtelności i niedookreśleń znaczenia artefaktów, niewyraźnych granic. Chcę dodać, że Japończycy również mają niekiedy problem z ustaleniem przynależności przestrzeni i artefaktów do obszaru ohyake lub watakushi i puraibashii. Moje trudności w zrozumieniu znaczeń powodowały z kolei pewne restrykcje i ograniczenia zastosowane wobec badaczki w terenie badawczym szkół i placówek dla dzieci, młodzieży i dorosłych z niepełnosprawnością. W konsekwencji jednak ograniczenia stosowane przez odźwiernych (gatekeeperów) wprowadzających w teren badawczy, stały się momentem krytycznym do właściwego rozumienia przestrzenie edukacyjnych, nadawanych im wartości oraz znaczenia artefaktów (behawioralnych i fizycznych) w kontekstach kategorii ohyake (公) (publiczne) oraz watakushi (私) i puraibashi (プライバシー) (prywatne).

Po trzecie, filarem badań $w$ reinterpretowanej i rozszerzonej przeze mnie formie była opublikowana w końcu lat 60. XX w., koncepcja siedmiu ról człowieka upośledzonego, determinująca modele wsparcia instytucjonalnego, autorstwa W. Wolfensbergera ${ }^{39}$. Badacz uważa, że

w instytucjach realizowanie roli podlega wpływowi nie tylko bodźców interpersonalnych, których doświadcza człowiek w nich przebywający ze strony personelu, lecz również bodźców obejmujących możliwości i wymagania środowiska fizycznego ${ }^{40}$.

W. Wolfensberger wskazał siedem ról ludzi upośledzonych i podejście do nich w modelach instytucji stacjonarnych, na tle kontekstów historycznych. Na drodze analiz krytycznych minionych, historycznie istniejących $\mathrm{w}$ kulturze przestrzeni, artefaktów materialnych i fizycznych obecnych w systemach wsparcia, autor wyróżnił typologie siedmiu ról ludzi z upośledzeniem. Koncepcja została opubliko-

\footnotetext{
38 Ibidem, s. 138.

${ }^{39} \mathrm{~W}$. Wolfensberger, op. cit.

40 Ibidem, s. 64.
} 
wana w 1969 r., a autor posłużył się sformułowaniem upośledzenie, co wskazuje związek z obowiązującą $\mathrm{w}$ tamtych latach terminologią diagnostyczną dotyczącą niepełnosprawności intelektualnej. W. Wolfensberger ${ }^{41}$ wyróżnił siedem ról człowieka upośledzonego (The Retardate) determinujących instytucjonalne modele wsparcia. Autor wskazał: (a) upośledzonego jako osobę chorą, (b) upośledzonego jako organizm człekokształtny, (c) upośledzonego jako zagrożenie, (d) upośledzonego jako obiekt litości, (e) upośledzonego jako obciążenie filantropią, (f) upośledzonego jako świętego niewinnego i (g) upośledzonego jako osobę rozwijającą się.

Chcę dodać, że z dzisiejszego punktu widzenia kategoryzowanie osób z niepełnosprawnością $\mathrm{w}$ badaniach pozaklinicznych budzi wiele wątpliwości akademików z obszaru studiów nad niepełnosprawnością i jest moim zdaniem niezręczne, jakkolwiek zauważam, że autor świadomie wskazane etykiety utworzył, podkreślając jednocześnie kuriozalność i ograniczenie ról. Niemniej jednak koncepcja W. Wolfensbergera wpisuje się terminologicznie oraz treściowo w krytykę systemów instytucjonalnego wsparcia końca lat 60. XX w. Koncepcja w pierwotnym kształcie wskazuje ograniczenia wynikające $\mathrm{z}$ czasu oraz ze zmian w projektowaniu przestrzeni dla osób z niepełnosprawnością w kulturze Zachodu. W konsekwencji pracy koncepcyjnej konstrukty $W$. Wolfensbergera ${ }^{42}$ poddałam gruntownej reinterpretacji $\mathrm{w}$ kontekstach: użytej terminologii, zakresu semantycznego koncepcji, ugruntowania we współczesnych studiach nad niepełnosprawnością, rozszerzenia modelu o wymiar placówek dziennego przebywania, zbudowania uniwersalnego wzoru kulturowego oraz przeniesienia punktu ciężkości z podmiotu na przestrzeń, którą postrzegam jako dominujący rezerwuar wiedzy kulturowej i konstruktów niepełnosprawności. Model nazwałam 10-wymiarowym kulturowo-przestrzennym rezerwuarem kodowania konstruktów niepetnosprawności. Wśród konstruktów teoretycznych reinterpretowanych wyróżniam zatem 10 w ujęciu chronologiczno-historycznym:

41 Ibidem.

42 Ibidem. 
Tabela 1. Kulturowo-przestrzenny rezerwuar kodowania konstruktów niepełnosprawności

1. Przestrzeń kultury jako rezerwuar konstruktu wskazującego traktowanie osoby niepetnosprawnej jako organizmu cztekoksztattnego

2. Przestrzeń kultury jako rezerwuar konstruktu wskazującego traktowanie osoby niepetnosprawnej jako zagrożenia

3. Przestrzeń kultury jako rezerwuar konstruktu wskazującego traktowanie osoby niepetnosprawnej jako obiektu litości

4. Przestrzeń kultury jako rezerwuar konstruktu wskazującego traktowanie osoby niepetnosprawnej jako obciażenia filantropią

5. Przestrzeń kultury jako rezerwuar konstruktu wskazującego traktowanie osoby niepetnosprawnej jako świętego niewinnego

6. Przestrzeń kultury jako rezerwuar konstruktu wskazującego traktowanie osoby niepetnosprawnej jako chorej

7. Przestrzeń kultury jako rezerwuar konstruktu wskazującego traktowanie osoby niepetnosprawnej jako rozwijającej się

8. Przestrzeń kultury jako rezerwuar konstruktu wskazującego traktowanie osoby niepetnosprawnej jako wykluczonej

9. Przestrzeń kultury jako rezerwuar konstruktu wskazującego traktowanie osoby niepetnosprawnej jako niezależnej

10. Przestrzeń kultury jako rezerwuar konstruktu wskazującego traktowanie osoby niepełnosprawnej jako samostanowiącego twórcy wtasnego życia ${ }^{43}$

Źródło: opracowanie własne Beata Borowska-Beszta

W konkluzji przeglądu literatury chcę dodać, że na podstawie badań terenowych, etnograficznych w kulturach niepełnosprawności i kulturze dominującej, realizowanych przeze mnie w latach 1999-2017 (lub realizowanych pod moim kierunkiem), uważam, że powyższe 10 kategorii przestrzeni kultury ma charakter uniwersalny zarówno w wymiarach kultury materialnej i przestrzeni rzeczywistych kultur: stacjonarnego lub dziennego wsparcia, edukacji osób z niepełnosprawnością, jak również w przestrzeniach wirtualnych kultur online. Powyższe trzy filary teoretyczne, czyli koncepcje E. Scheina ${ }^{44}$, T. Takamury ${ }^{45}$ oraz moja koncepcja stanowiąca

${ }^{43}$ Pogłębionym analizom modelu poświęce odrębną publikację.

${ }^{44}$ E.H. Schein, op. cit.

${ }^{45}$ T. Tamura, op. cit. 
rozwinięcie, reinterpretację koncepcji W. Wolfensbergera ${ }^{46}$, posłużyły jako grunt prowadzonych analiz na etapach kodowania i kategoryzacji oraz generowania tematów kulturowych $\mathrm{w}$ czasie i po realizacji badań w terenie japońskim. Do nich również odniosłam się w dyskusji badań terenowych, przestawionej w niniejszym raporcie.

\section{Metoda - etnografia wizualna - mikroetnografia}

Badania artefaktów szkolnych zostały zaprojektowane zgodnie z koncepcjami badań etnograficznych, mikroetnograficznych, wizualnych i ugruntowane $\mathrm{w}$ antropologii kulturowej uczonych cytowanych w ramach teoretycznych projektu i przeglądzie literatury. Próba celowa $\mathrm{w}$ niniejszym raporcie $\mathrm{z}$ badań obejmowała wizyty w sześciu specjalnych i inkluzyjnych szkołach publicznych dla dzieci i młodzieży $\mathrm{z}$ niepełnosprawnością oraz $\mathrm{w}$ jednym ośrodku wsparcia dorosłych ze złożoną niepełnosprawnością intelektualną stopni: umiarkowanego, znacznego i głębokiego. W trakcie wizyt terenowych wykonałam obserwacje uczestniczące, nieuczestniczące oraz wykonałam łącznie 414 fotografii stanowiących dokumentację wizualną badanych miejsc. Dostęp do badań łącznie w siedmiu ośrodkach edukacyjnych i wspierających oraz czas gromadzenia danych ukierunkował badania w kierunku mikroetnografii, zawężonej w niniejszym raporcie do szczególnego, jednego aspektu badanej rzeczywistości szkolnej, a mianowicie przestrzeni i artefaktów fizycznych - materialnych. Do analizy wybrałam jedynie fotografie, które ilustrowały wewnętrzne przestrzenie oraz artefakty szkolne. Jako pewne ograniczenie uważam to, że nie wolno mi było fotografować twarzy uczniów w przestrzeni szkoły, przez co szkoły i przestrzeni sprawiają $\mathrm{w}$ raporcie wrażenia miejsc wyludnionych, a tak $\mathrm{w}$ istocie nie było. Co więcej, w niektórych zajęciach praktycznych uczyłam się od gimnazjalistów z niepełnosprawnością intelektualną ich zadań, praktycznie wykonując czynności np. robienia papieru

${ }^{46} \mathrm{~W}$. Wolfensberger, op. cit. 
mache, tkactwa i innych. Tych danych również nie było wolno mi zarejestrować aparatem fotograficznym. Kroki postępowania badawczego oparte były na koncepcji badawczej J. Spradleya ${ }^{47}$ i T.L. Whiteheada ${ }^{48}$ i obejmowały:

- analizę literatury naukowej,

- analizę wtórną innych danych zastanych,

- prace $\mathrm{w}$ terenie: gromadzenie danych wizualnych i werbalnych, analizy wstępne danych,

- rekurencję, dyskusję i analizy danych jakościowych,

- pisanie raportu z badań i eseju etnograficznego.

\section{Gromadzenie danych}

Dane w zrealizowanej mikroetnografii wizualnej były gromadzone za pomocą aparatu fotograficznego Huwawei z telefonu komórkowego. Uważam, że niewielki sprzęt miał znaczenie i nie powodował dyskomfortu Japończyków. Dane gromadziłam jawnie, mając uprzednie niezbędne zgody dyrektorów sześciu szkół, jednego ośrodka wsparcia dorosłych oraz opiekuna stażu naukowego Profesora N. Tasaki, na wykonywanie 414 zdjęć i rozmowy z nauczycielami lub terapeutami. Celowość wykonywania dokumentacji fotograficznej do badań była uzgodniona uprzednio przez opiekuna stażu z dyrektorami każdej z wizytowanych szkół oraz ośrodka wsparcia i oparta na ustnej zgodzie, wskazanej przez metodologów: Green \& Blooma ${ }^{49}$. Z relacji ustnej opiekuna stażu wiem, że uzyskanie zgody na wejście do szkół oraz gromadzenie danych nie było łatwym zadaniem. Wymagało dyplomacji i głębszego uzasadnienia

47 J. Spradley, The Ethnographic interview, Holt, Rinehart \& Winston, New York 1979; J. Spradley, Participant observation, Holt, Rinehart \& Winston, New York 1980.

48 T.L. Whitehead, Basic Classical Ethnographic Research Methods Secondary Data Analysis, Fieldwork, Observation/Participant Observation and Informal and Semistructured Interviewing, 2005. http://www.cusag.umd.edu/documents/working papers/classicale thnomethods.pdf [dostęp: 4.07.2017].

49 J.L. Green, D. Bloome, op. cit., s. 181-202. 
wejścia w teren. Oprócz danych fotograficznych w edukacyjnych kulturach organizacyjnych, przeprowadziłam rozmowy z dyrektorami: naczelnymi, zwanymi kōchō sensei (校長先生) (principal i $d y$ rektor szkoły) i zastępcami, każdej ze wskazanych szkół, zwanymi kyoutou sensei (教頭先生) (head teacher), anglistami i innymi. Rozmowy $\mathrm{z}$ anglistami było mocno osobliwe. Ta grupa nauczycieli mówiła do mnie niemal szeptem, powściągliwie, uśmiechając się przyjaźnie i poruszając bardzo powoli. Angliści cedzili słowa, sprawiając, że rozmowy o sprawach służbowych w kontekstach służbowych przypominały intymne zwierzenia. Zwykle przestrzeń między nimi a mną była mniejsza niż 50-30 cm. Zauważałam, że angliści byli dyskretnie, lecz cały czas obserwowani przez któregoś z dyrektorów. Mieli tego świadomość. Gdy ujawniali mi jakieś trudności w pracy, np. brak odpowiedniego wykształcenia specjalistycznego do pracy $\mathrm{z}$ niepełnosprawnymi, ich szept po angielsku był niemal niesłyszalny. Dostosowałam się do ich zachowania i sposobu komunikacji, lecz często musiałam dopytywać o szczegóły. Zjawisko obserwowałam kilkakrotnie. Gromadzenie danych realizowałam w następujących specjalnych i inkluzyjnych szkołach publicznych, a także ośrodku wsparcia, wskazanych w tabeli:

Tabela 2. Przestrzenie edukacyjne gromadzenia danych

1. Zespół Szkół Specjalnych Koga: (Prefektural Koga Special Needs Education Schools in Koga)

- Szkoła Podstawowa Specjalna (Special Elementary School),

- Gimnazjum Specjalne (Special Junior High School).

2. Centrum Wsparcia Dorosłych z Niepełnosprawnością Momochi (Fukuoka City Momochi Welfare Center)

3. Uniwersytecka Szkoła Specjalna i klasy inkluzyjne Uniwersyteckiej Szkoły Ogólnodostępnej: (Schools Attached to University of Teacher Education in Fukuoka UTEF)

- Uniwersytecka Szkoła Podstawowa z klasami inkluzyjnymi (Fukuoka UTEF Primary School),

- Uniwersyteckie Gimnazjum z klasami inkluzyjnymi (Fukuoka UTEF Junior High School),

- Uniwersytecka Szkoła Specjalna (Fukuoka UTEF Special School).

4. Szkoła ogólnodostępna z klasami specjalnymi i inkluzyjnymi

- Zespół Szkół Podstawowych, Munakata (Primary Schools, Munakata) 


\section{Teren badań}

Miejscem pełnych badań terenowych była Wyspa Kyushu w Japoni, miasto portowe Fukuoka w Prefekturze Fukuoka oraz dwa uniwersytety japońskie - prywatna uczelnia: Kyushu Women's University i uczelnia państwowa: University of Teacher Education in Fukuoka. Ponadto szkoły specjalne, inkluzyjne oraz placówka wsparcia młodzieży i dorosłych z niepełnosprawnościami intelektualnymi. Badania prowadziłam w maju 2016 r. w trakcie stażu naukowego od 16 do 22 maja 2017 r. Stażem naukowym w Japonii kierował Profesor Noritomo Tasaki, pedagog, komparatysta, obecnie emerytowany lecz nadal czynny zawodowo i akademicko, profesor dwóch uniwersytetów: Kyushu Women's University i University of Teacher Education in Fukuoka. Opiekun stażu, profesor N. Tasaki, ustalił dla mnie indywidualny harmonogram stażu, a w tym zakres prac badawczych, zajęć uniwersyteckich, mityngów naukowych i terenowych w Japonii. Dzięki jego autorytetowi i pozycji naukowej oraz wielu szerokim, zawodowym kontaktom miałam możliwość unikatowego oglądu szkół edukacji specjalnej, inkluzyjnej, które byłyby niedostępne bez poręczenia osobistego, co wiązało się szczególnie z osobistym autorytetem profesora N. Tasaki w kulturach akademickich i kulturach organizacyjnych szkół i placówek wsparcia. Poniżej przedstawiam założenia badawcze odniesione jedynie do raportu obejmującego część badań artefaktów i znaczeń kulturowych w edukacyjnych kulturach edukacji specjalnej i inkluzyjnej w Japonii. Pomijam $\mathrm{w}$ niniejszym raporcie problemy badań fenomenu twarzy jako symbolu kulturowego, pomijam badania związane z podmiotami edukacji specjalnej, szokiem kulturowym oraz problematyką metodologiczną władzy gate-keepera w terenie, w Japonii oraz szczegółowe badania dotyczące innych niż wybrane przestrzenie i fizyczno-materialne artefaktów edukacyjnych kultur organizacyjnych w Japonii, wskazanych w publikacjach przez E. Scheina ${ }^{50}$, które również realizowałam podczas stażu naukowo-

${ }^{50}$ E. Schein, op. cit. 
-badawczego. Poniższy raport skoncentrowałam wyłącznie na deskrypcji i analizach przestrzeni i znaczeń fizyczno-materialnych artefaktów edukacyjnych. Opiekun stażu profesor N. Tasaki wielokrotnie podkreślał, że organizacja wizyt w szkołach specjalnych jest zadaniem trudnym organizacyjnie, co również dało mi do myślenia o dostępności obszarów praktyki związanych z niepełnosprawnością w Japonii dla osób z zewnątrz.

W tej części badań postawiłam pytanie badawcze główne, które rekapituluję dla poprawy czytelności tekstu:

Jakie sa przestrzenie, artefakty oraz nadawane im kulturowe znaczenia $w$ kulturach organizacyjnych systemu edukacji specjalnej i inkluzyjnej w Japonii?

W praktyce terenowej okazało się, że przestrzenie i artefakty są powiązane $z$ innymi elementami kultury organizacyjnej wskazywanymi przez E. Scheina ${ }^{51}$, takimi jak normy, rytuały, wartości, symbole, które również poznawałam i do których się odniosę częściowo $\mathrm{w}$ niniejszym raporcie $\mathrm{z}$ badań.

\section{Negocjacje wejścia w teren}

Przed udaniem się do Japonii i $\mathrm{w}$ teren opiekun stażu prof. N. Tasaki kilkakrotnie poprosił, abym wyposażyła się w wizytówki, stosowny ubiór oraz bardzo delikatnie i niewprost zasugerował, abym opanowała umiejętności wymiany wizytówek, co było wprowadzeniem do poznania zarówno do artefaktów fizycznych, jak $\mathrm{i}$ behawioralnych. Bycie $\mathrm{w}$ terenie wymagało zatem ode mnie wstępnej znajomości rytuałów i etykiety podczas mityngów służbowych oraz czynności koniecznych podczas spotkań, a w tym:

- posiadania wizytówek oraz umiejętności wymiany wizytówek podczas mityngów służbowych i badań;

- odpowiedniego powściągliwego i pogodnego zachowania podczas spotkań z władzami uczelni, szkół itp.;

51 Ibidem. 
- umiejętności samodzielnego dojazdu pociągiem linii lokalnych do wybranych miejsc w terenie badawczym, umiejętność poruszania się $\mathrm{w}$ terenie i komunikacji, mimo iż opiekun stażu niejednokrotnie towarzyszył mi podczas gromadzenia danych w terenie, zwłaszcza gdy wiedział, że w danym miejscu znajomość języka angielskiego wśród pracowników edukacyjnych kultur organizacyjnych jest znikoma;

- obowiązku stosownego i oficjalnego ubioru, koniecznego do wejścia do placówek edukacyjnych. Tradycyjny i oficjalny ubiór oznacza: czarną garsonkę, jasną bluzkę, rajstopy, półbuty pełne, dyskretną biżuterię, płaskie i zwłaszcza ciche obuwie dla kobiet. Wysokie obcasy były niewskazane z powodu zakłócania spokoju i ciszy osób w edukacyjnych scenach kulturowych, na co zwrócił mi uwagę i szczególnie podkreślił profesor N. Tasaki. Ciche obuwie jest bowiem wyrazem szacunku dla miejsca oraz uczących się. Wskazane były zatem półbuty ciche, niezakłócające innym ich spokoju. Szpilki i wysokie obcasy w półbutach damskich okazały się pomysłem niestosownym.

Wejście w teren wymagało dostosowania się do reguł spotkań oficjalnych w strukturach szkoły. Poniżej wskazuję elementy artefaktów behawioralnych podczas wizyt. Były wśród nich następujące reguły i normy:

- konieczność zwyczajowego kłaniania się podczas spotkań z dyrekcjami, nauczycielami i po wizytach, rozmowach. Utrzymywanie kontaktu wzrokowego i bezdotykowego, co wykluczało podawanie rąk;

- konieczność wymiany wizytówek, powściągliwość w gestykulacji, uprzejma pogodna powaga w zachowaniu (uśmiech szeroki bądź śmiech ma znaczenie binarne i zalecana jest powściągliwość w wyrażaniu emocji);

- konieczność każdorazowej zmiany obuwia w szkołach na klapki szkolne (czerwone, zielone, niebieskie, beżowe) podczas wizyt w każdej szkole podstawowej lub gimnazjum i odpowiedniego ustawienia własnego obuwia (nosami do wyj- 
ścia) przed drzwiami wyjściowymi głównymi z budynku w przestrzeni zwanej w Japonii genkan (玄関);

- konieczność indywidualnego uzgadniania wykonania każdej fotografii w terenie badawczym, którą wykonywałam w dowolnym miejscu podczas stażu wewnątrz uniwersytetów i placówek edukacyjnych oraz ośrodka wsparcia;

- podporządkowanie się i respektowanie zakazu ujawniania w fotografiach twarzy dzieci, młodzieży i dorosłych z niepełnosprawnością intelektualną w każdej placówce.

\section{Analiza danych}

Analiza danych tej części badań była prowadzona symultanicznie $\mathrm{w}$ trakcie gromadzenia danych $\mathrm{w}$ maju $2016 \mathrm{r}$. oraz przez ok. sześć miesięcy po zakończeniu gromadzenia danych terenowych w Japonii. Prowadzone analizy obejmowały kodowanie i kategoryzację według U. Flicka ${ }^{52}$ i G. Gibbsa ${ }^{53}$, dotyczącą uporządkowania kodowania i kategoryzowania przestrzeni i artefaktów materialno-fizycznych, zwłaszcza tych istniejących na styku przestrzeni ohyake (公), watakushi (私) i puraibashii (プライバシー) oraz analiza tematów kulturowych ${ }^{54}$ polegająca na generowaniu szerszych wzorów wpisujących się w kategorie przestrzeni publicznych i prywatnych. Tematy kulturowe były generowane w dwóch warstwach: realnej i symbolicznej kodowania znaczenia tego, co publiczne i tego, co prywatne w japońskim systemie edukacji specjalnej i inkluzyjnej.

52 U. Flick, Projektowanie badania jakościowego, PWN, Warszawa 2010.

53 G. Gibbs, Analizowanie danych jakościowych, PWN, Warszawa 2010.

54 B. Borowska-Beszta, Etnografia stylu życia...; B. Borowska-Beszta, Analiza antropologiczna jako transformacja: Problemy $i$ techniki generowania tematów kulturowych, „Problemy edukacji rehabilitacji socjalizacji osób niepełnosprawnych: Wybrane zagadnienie metodologii i metodyki badań w obszarze niepełnosprawności icodzienności osób z niepełnosprawnością" 2016, Vol. 23. 


\section{Wyniki badań}

\section{Przestrzenie ohyake (公) watakushi (私) i puraibashii (プライバシー) oraz artefakty systemu edukacji specjalnej i inkluzyjnej w Japonii}

Zanurzenie w wybrane japońskie edukacyjne kultury organizacyjne i przestrzenie ohyake (公), watakushi (私) i puraibashii (プラ イバシー) systemu edukacji specjalnej w Japonii ujawiło kwestie problematyczne związane z określeniem przyporządkowania szkół do przestrzeni publicznej i jej zakresu i prywatnej. Każda bowiem szkoła podstawowa, gimnazjum lub nawet obie uczelnie wyższe znajdowały się za murem z bramą elektronicznie otwieraną oraz niekiedy z obecnym przy niej umundurowanym strażnikiem.

Ponadto każda szkoła podstawowa specjalna, inkluzyjna i gimnazja, które wizytowałam, miały genkan (玄関) i założenie obowiązku

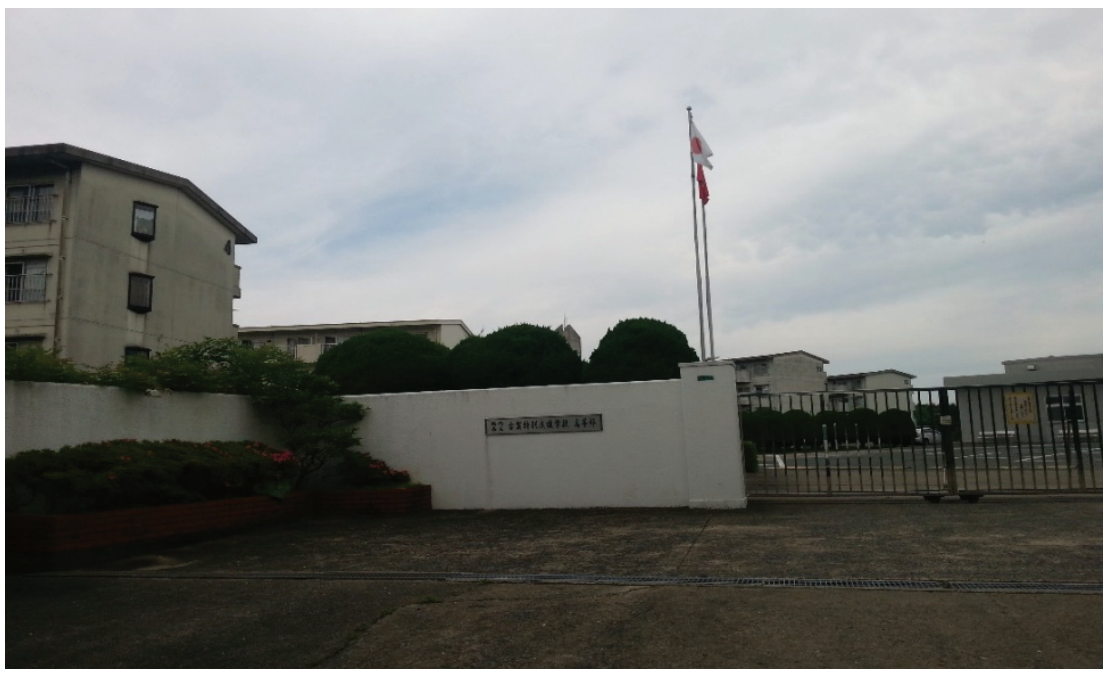

Fot. 1. Zespół Szkół Specjalnych Koga

Fot. Archiwum prywatne B. Borowska-Beszta 
zdejmowania oraz zmiany obuwia na klapki stanowiące wyposażenie szkoły. Zmiana obuwia nie dotyczyła przestrzeni uniwersytetów Kuyshu Women's University ani University of Teacher Education in Fukuoka z wyjątkiem sal seminaryjnych, w których odbywało się obowiązkowe tradycyjne nauczanie parzenia herbaty i tradycji japońskich. Ponadto okazywało się, że wizerunki szkół i uczelni w mediach internetowych mają wyjątkowo skąpe dane o władzach, pracownikach, miejscach co oznacza m.in. pomijanie nazwisk i e-maili oraz wizerunków fotograficznych władz rektorskich lub pracowników. Takie oczywiście reguły wytłumaczono mi tym, że twarz jest sprawą prywatną, nawet jeśli chodzi o władzę uczelni wyższej, nazwisko rektora też nie musi być znane, podobnie nazwisko dyrektorów szkół. Było to mocno zaskakujące wyjaśnienie. Bardzo natomiast chętnie Japończycy pozowali do fotografii grupowych z osobami z zewnątrz np. ze mną. Prowadzone badania wykazały, że przestrzenie i artefakty materialno-fizyczne, takie jak: budynki, przestrzenie wewnętrzne szkół specjalnych i ogólnodostępnych z klasami inkluzyjnymi, są miejscami o niejasnych granicach lokalizacji symbolicznej i znajdują się bliżej przestrzeni watakushi (私) i puraibashii (プライバシー) niż, co wcześniej zakładałam, w przestrzeni publicznej - ohyake (公). Natomiast wewnątrz samych kultur organizacyjnych zauważałam dążność do dostępności przestrzeni i jej transparentności. Szkoły miały pewne cechy charakterystyczne dla budowy szkół japońskich w ogóle, ale również zauważałam dostosowanie ich do specjalnych potrzeb edukacyjnych dzieci i młodzieży z niepełnosprawnością.

\section{Surippa (スリッパ) po wejściu i ocha (お茶) z dyrekcją szkół}

Każda pojedyncza wizyta w szkole rozpoczynała się punktualnym przybyciem do szkół powitaniem przez nauczycieli prowadzących i opiekunów wizyty oraz obowiązkową zmianą obuwia na klapki szkolne dla gości (bez względu na ich status społeczny) zwane surippa (スリッパ). Były one koloru czerwonego, zielonego, 
błękitnego i inych z inskrypcją po japońsku koloru złotego. Nosi się je $w$ miejscach, gdzie obuwie, $w$ którym chodzi się na zewnątrz budynku, jest zakazane. Podobne klapki nosi się $\mathrm{w}$ toaletach $\mathrm{w}$ domach japońskich. W dwóch szkołach na tablicach napisano specjalne powitanie dla mnie gościa z Polski po japońsku, w klasach inkluzyjych szkoły podstawowej $\mathrm{w}$ Munakata otrzymałam nawet wycięte przez ucznia z niepełnosprawnością intelektualną czerwone serce $\mathrm{z}$ życzeniami i przyklejoną jego uśmiechniętą fotografią. Był to ważny gest symboliczny - otrzymałam bowiem i serce, i twarz. Wizyty rozpoczynało każdorazowo wspólne wypicie zielonej herbaty, zwanej ocha (お茶) z dyrekcją szkół i zawsze z nauczycielami stojącymi na czele Rad Pedagogicznych oraz wspólne wstępne rozmowy i ustalanie planu gromadzenia danych. Herbatą zwykle częstował w swoim biurze kōchō sensei (校長先生) (principal dyrektor szkoły), reprezentujący szkołę na zewnątrz, w kontekstach wizyt oficjalnych, ceremonii i w kwestiach dyplomatycznych oraz czasem wicedyrektor szkoły, zwany kyoutou sensei (教頭先生) (head teacher), odpowiedzialny za bieżące codzienne funkcjonowanie szkoły z zaakcentowaniem spraw dydaktyczno-wychowawczych. W strukturze władz szkół japońskich jest jeszcze trzeci dyrektor zwany kyoumu sensei (教務先生), który zajmuje się planem szkolnym. Zwykle wizytom w szkołach i terenie badawczym towarzyszyło na początku dwóch dyrektorów, natomiast po szkole zawsze oprowadzał zawsze kyoutou sensei (教頭先生) (head teacher - zastępca dyrektora, nauczyciel wiodący). Zwykle to kyoutou sensei (教頭先生) odpowiadał chętniej na pytania, prowadził rozmowę, dawał wyjaśnienia $\mathrm{w}$ razie wątpliwości. Czasem się dziwiłam, dlaczego dyrekcja i organizatorzy wizyt nie wybrali do tej roli anglistów, ponieważ bywało, że kyoutou sensei (教頭先生) znał słabiej język angielski i często nadrabiał uprzejmym uśmiechem niż udzielał wyczerpującej odpowiedzi. Wyjaśnieniem były pewne ciekawe obserwacje dotyczące hierarchii władzy w szkołach. W kilku szkołach, gdy spontanicznie podchodzili do mnie angliści, aby porozmawiać, odbywało się to $\mathrm{w}$ osobliwy sposób, o czym wspomniałam w raporcie, a mianowicie mówili szeptem, bardzo powściągliwie, co 
wówczas mnie nieco dziwiło. Głośno mówiono w moim towarzystwie po japońsku, jakby dając publiczny wyraz priorytetu języka japońskiego. Mimo to, w szkołach jest jeszcze jedna funkcja tantousha (担当者) superwizora w Radzie Pedagogicznej każdej szkoły. Zwykle jest to nauczyciel języka angielskiego, odpowiedzialny za naukę tego języka. Następnie w kolejności odbywały się wizyty całych przestrzeni szkolnych i kolejno hospitacje lekcji lub zajęć $\mathrm{z}$ dziećmi, młodzieżą z niepełnosprawnością intelektualną w stopniach lekkim, umiarkowanym i znacznym. W miarę swobodnie mogłam fotografować puste korytarze i puste klasy szkolne. Za każdym razem otrzymywałam werbalnie normy szkoły i zalecenie niefotografowania twarzy uczniów. Chodziło o to, że twarze uczniów powinny zostać anonimowe. Czasem mogłam jedynie fotografować uczniów pełnosprawnych lub z niepełnosprawnością siedzących plecami do mnie lub z oddali. Na korytarzu przy klapkach zrobiłam przypadkowo zdjęcie chłopca, który bardzo chciał być sfotografowany i często wchodził mi w kadr. Zakodowałam jego twarz $\mathrm{w}$ raporcie $\mathrm{z}$ badań, gdy usiadł do zdejmowania obuwia w genkan. Żałuję, że nie mogłam robić żadnych zdjęć z pracowni dziewiarskiej - tkackiej, pracowni ceramicznej, a szczególnie pracowni tworzenia papieru mache, którego wyrobu uczyła mnie w praktyce młodzież japońska z niepełnosprawnością intelektualną w stopniu umiarkowanym, z japońskiego gimnazjum w Kodze. Były to żywiołowe i spotaniczne spotkania. Przechodząc do analiz przestrzeni, miejsce oglądanej lekcji w Uniwersyteckiej Szkole Specjalnej (UTEF) pokazała przestrzeń zadbaną, jasną, doświetloną światłem naturalnym, czystą, gładką, uporządkowaną, minimalistyczną w wyrazie i ascetyczną. Mogłam zauważyć, że szkoła uniwersytecka dysponuje prawdopodobnie większymi środkami finansowanymi niż placówki szkolne poza uniwersyteckie. Na lekcji muzyki, rytmiki i głoskowania $\mathrm{w}$ grupce dziesięciorga szczuplutkich dzieci $\mathrm{z}$ niepełnosprawnością intelektualną $\mathrm{w}$ stopniu umiarkowanym, m.in. z zespołem Downa, oprócz nauczycielki było dwóch mężczyzn, studentów praktykantów. Małe dzieci, dzieci i młodzież mijane na korytarzach cechowała werbalna uprzejmość, gdyż zawsze każdemu z osobna 


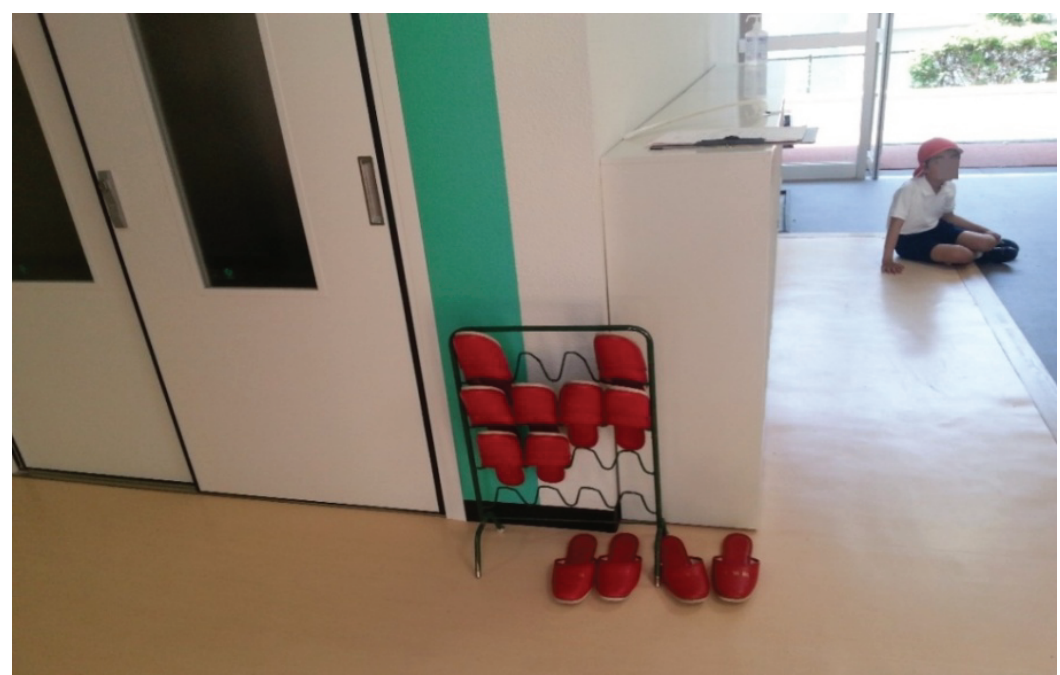

Fot. 2. Surippa (スリッパ ) - klapki szkolne dla gości wiszą na specjalnym stojaku Źródło: archiwum prywatne B. Borowska-Beszta

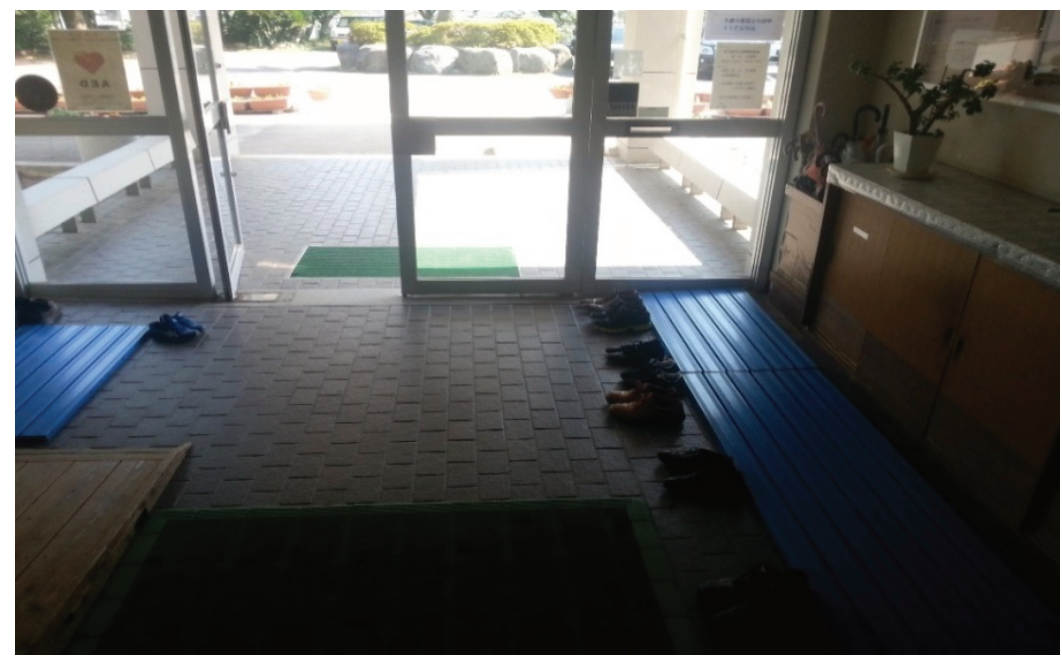

Fot. 3. Genkan (玄関)

Źródło: archiwum prywatne B. Borowska-Beszta 
mówiły z uśmiechem konnichiwa (dzień dobry!) na, co oczywiście odpowiadałam również z uśmiechem i ukłonem. Obcy nauczyciele również kłaniali się, mówiąc konnichiwa. Dzieciom zalecano, aby nie biegały po korytarzach lecz spokojnie chodziły.

\section{Artefakty fizyczno-materialne korytarzy i klas szkolnych}

Genkan (玄関) jest pierwszym ważnym symbolicznie miejscem symbolicznej i rzeczywistej puryfikacji podczas wejścia do każdej z sześciu szkół podstawowych i gimnazjów, które wizytowałam i w których gromadziłam dane. Wejście do placówki wsparcia dorosłych, placówki opiekuńczej nie miało przestrzeni genkan (玄関) i nie wymagało zmiany obuwia. Genkan (玄関) ma znaczenie psychologiczne i symboliczne w tradycji Japonii. Stanowi psychologiczną granicę między światem zewnętrznym i przestrzenią ohyake i światem wewnętrznym domu, szkoły - watakushi i puraibashii ${ }^{55}$. Genkan (玄関) jako przestrzeń graniczna tego, co ohyake i tego, co watakushi i puraibashii jest w tradycji japońskiej związana historycznie ze świątyniami ZEN oraz domami samurajów. Jest istotnym miejscem puryfikacji i zaznaczenia granicy oraz ważnego momentu tranzytu ze świata zewnętrznego ohyake do wewnętrznego watakushi i puraibashii szkół. Szkoły podstawowe i gimnazja uwzględniające przestrzeń genkan (玄関) wskazują czytelnie, z jednej strony konieczność symbolicznego oczyszczenia myśli (lecz nie tylko) przed wejściem do kultur szkolnych, $\mathrm{z}$ drugiej strony stanowią moment zrównania podmiotowego statusu gości, a ponadto pokazują granice prywatności i tego co publiczne. Z perspektywy europejskiej wydawać by się mogło, że szkoła jest przestrzenią publiczną, natomiast z perspektywy Japonii te granice nie są już oczywiste. Podczas pierwszej zmiany obuwia w wizytowanym gimnazjum specjalnym w Kodze, w którym gromadziłam dane, ustawiłam nieprawidłowo własne czółenka w genkan (玄関). Dyrektor szkoły

${ }^{55}$ F. Asako, What is Genkan?, "Nipponia” 2002, nr 20, March 15, http://webjapan.org/nipponia/nipponia20/en/what/what01.html [dostęp: 4.07.2017]. 
zareagował błyskawicznie i przed wejściem na korytarz szkolny osobiście przestawił moje buty prawidłowo, dając mi sygnał o znaczeniu genkan (玄関), a ja się szybko się nauczyłam, jak to należy robić. Całe błyskawiczne zdarzenie nie było reprymendą $\mathrm{w}$ moim kierunku lecz naturalnym gestem, wobec moich szybkich lecz czasem nieporadnych prób poradzenia sobie z wąską spódniczką garsonki, zdejmowaniem sznurowanych czółenek na stojąco i tym, że głównie mężczyźni czekali na mnie najdłużej oraz przyglądali się temu, co pospiesznie robię. $Z$ tego powodu moment zakładania i zdejmowania obuwia miał wymiar genderowy i powodował pewne napięcia sytuacyjne. Nikt mnie jednakże w żaden sposób nie popędzał. Genkan (玄関) wymaga od osoby wchodzącej dokonania fizycznej zmiany obuwia oraz zmiany symbolicznej, polegającej na zostawieniu dosłownego i metaforycznego „brudu” na zewnątrz. Gdy zmieni się obuwie na klapki symbolizujące w szkołach przestrzeń domu, niedozwolone jest wychodzenia klapkami w kierunku drzwi wejściowych do budynku lub poza budynek.

Korytarze w wizytowanych szkołach specjalnych lub ogólnodostępnych z klasami inkluzyjnymi i specjalnymi były przestrzenne i dobrze oświetlone. Mijały mnie dzieci umundurowane i poruszające się w szyku znanym w Polsce, jako tzw. gęsiego. Minimalistyczne w projektach i puste korytarze, miały zazwyczaj jakiś jeden kolorowy akcent, jedną tablicę artystyczną i symboliczną w formie, lecz nie było korytarzy przeładowanych na ścianach znakami, tekstami, ogłoszeniami i znaczeniami. Były miejsca minimalistycznie puste, lecz nie sprawiały wrażenia chłodnych i zdystansowanych instytucji. Z korytarzy można było oglądać lekcje, gdyż ściany od ich strony na ogół były przeszklone i transparentne. Można było wchodzić do klas, w których nie było lekcji lub oglądać te, w których odbywały się lekcje, wchodząc do klas lub obserwując z korytarza lekcje. Skupieni uczniowie nie reagowali na wejścia. Na holach szkoły ogólnodostępnej z klasami inkluzyjnymi i specjalnymi, transparentnych i czystych znajdowały się przymocowane wieszaki z workami rzeczy osobistych dzieci, ale też inne przedmioty, jak np. ławka z oparciem, umywalka długa na ok. $3 \mathrm{~m} \mathrm{z}$ kranami i mydłem 
na korytarzu prowadzącym do biblioteki. Przeważającymi barwami korytarzy były kolory kremowy i écru oraz miękka biel. Zarówno w szkołach specjalnych dla poziomów podstawowego i gimnazjum, jak i w szkole ogólnodostępnej z klasami inkluzyjnymi i specjalnymi przestrzenie ścian szkolnych korytarzy nie epatowały raczej kolorem i tym bardziej pstrym chaosem lecz pojedynczymi tablicami. Przeszklone korytarze dodawały pewności, że to, co się dzieje w klasach, jest transparentne, a klasy znajdowały się pod kontrolac władz szkolnych. Niejednokrotnie, przechadzając się po korytarzach, byłam zaintrygowana ciszą na lekcjach, zwłaszcza w szkole ogólnodostępnej z klasami inkluzyjnymi i specjalnymi, gdzie w klasach regularnych znajdowało się po 40 dzieci. Cisza i skupienie panowały również $\mathrm{w}$ wydzielonych klasach specjalnych, które liczyły po kilkoro dzieci (4-10).

Klasy w szkołach specjalnych i ogólnodostępnej z klasami inkluzyjnymi i specjalnymi miały stoliki pojedyncze dla dzieci i młodzieży z niepełnosprawnością intelektualną, zwanych - chiteki shōgai (知的障害) - zwrócone w stronę tablicy, ustawione prosto lub po łuku. Miałam wrażenie, że nie są sztywno umieszczone, że mogą być przestawiane zgodnie z potrzebami dydaktyczno-wychowawczymi. Klasy lekcyjne były dobrze doświetlone miękkim światłem naturalnym i lampami. Każda klasa miała okna niemal na całych ścianach. Klasy miały często klarowny podział przestrzeni podzielonej na (a) przestrzeń pracy indywidualnej, (b) przestrzeń pracy zespołowej i zabaw oraz (c) pustą przestrzeń pomiędzy obiema wyżej wspomnianymi. Owa przestrzeń pusta wydała mi się szczególnie interesująca, gdyż z jednej strony umożliwiała swobodę uczniom: można było pochodzić sobie gdy dziecko miało potrzebę, a z drugiej podjęcie takich form edukacyjnych, które nie wpisywały się $\mathrm{W}$ przestrzenie pracy indywidualnej lub zespołowej. Podobny wystrój był w szkole ogólnodostępnej z klasami inkluzyjnymi, w której prowadzono odrębne klasy specjalne, kilkuosobowe dla dzieci z różnorodnymi zaburzeniami: w sferze sensorycznej, zaburzeniami emocjonalnymi (zaburzeniami ze spektrum autyzmu), niepełnosprawnością intelektualną, zaburzeniami zachowania. 
Te klasy również miały klarowny podział przestrzeni na przestrzeń do pracy indywidualnej, odgrodzonej parawanami różnego typu, dla dzieci z zaburzeniami ze spektrum autyzmu oraz do pracy grupowej po drugiej stronie klasy, również z wydzielonymi przestrzeniami, batutą. W klasach nie było dywanów, wykładzin dywanowych lecz gładki parkiet lub rodzaj trwałych niezwykle gładkich, jasnych posadzek. Ciekawym rozwiązaniem w klasach specjalnych szkoły ogólnodostępnej było użycie piłek tenisowych do wygłuszania nóg krzeseł i stolików ustawionych na parkiecie. Cisza podczas lekcji i nieprzeszkadzanie innym ma kluczowe znaczenie w kulturze Japonii, w dowolnych przestrzeniach życia społecznego. Wizytując klasy, w których odbywały się lekcje, obserwowałam pracę dzieci i młodzieży, ich skupienie i niekiedy zainteresowanie wizytującymi. Co ciekawe, w jednej szkole ogólnodostępnej z klasami specjalnymi połowa szkoły była przeznaczona dla uczniów pełnosprawnych, a połowa dla dzieci z dysfunkcjami i specjalnymi potrzebami edukacyjnymi. Intrygujący był sposób funkcjonowania szkoły oraz informacje, jakie otrzymałam od nauczycieli o tym, że rodzice dzieci pełnosprawnych mieli osobne wejście i nie wiedzieli o tym, że jedno skrzydło szkoły przeznaczone jest dla dzieci z niepełnosprawnością. To wyjaśnienie kulturowe dało mi pewne przypuszczenia odnośnie do symbolu kulturowego i znaczenia fenomenu niepełnosprawności intelektualnej - chiteki shōgai (知的障害) $\mathrm{w}$ Japonii. Znaczenie tego fenomenu przeanalizuję w kolejnej publikacji z cyklu badania systemu edukacji w Japonii.

W klasach szkolnych szkoł specjalnych, szkoły ogólnodostępnej z klasami inkluzyjnymi i specjalnymi, które wizytowałam znajdowały się oprócz tablicy, pojedynczych lub dwuosobowych stolików dla dzieci i młodzieży również niezamykane szafki na mundurki szkolne, w których dzieci zostawiały mundurki, gdy udawały się na lekcje wychowania fizycznego. Ponadto stałym elementem aranżacji przestrzeni były parawany różnego typu, dzielące przestrzenie na przestrzeń pracy indywidualnej oraz zespołowej.

Parawany znajdowały się w klasach w których uczyły się dzieci i młodzież zwłaszcza z zaburzeniami ze spektrum autyzmu. Parawa- 
ny były także stałym elementem wnętrz w Centrum Wsparcia Dorosłych z Niepełnosprawnością Momochi. Zwykle miały one różnorodne faktury od płóciennych do drewnianych czy też tekturowych. Bywały transparentne (przypominające klatki) i ogrodzenia, które symbolicznie zamykały przestrzeń i fizycznie ją dzieliły. Parawany są również stałym elementem i historycznie obecnym artefaktem kultury japońskiej. Nie zauważyłam, aby dzieci kontaktowały się między sobą przez parawany różnego typu. Były zaabsorbowane własną pracą. Ciekawym miejscem szkół były biblioteki szkolne. W szkole ogólnodostępnej z klasami inkluzyjnymi i specjalnymi na korytarzu przed wejściem do biblioteki zamocowana była długa na ponad $3 \mathrm{~m}$, wielostanowiskowa umywalnia z kilkoma kranami, mydłami w plastikowych siatkach oraz przypomnieniem pisemnym z zaleceniem umycia rąk przed wejściem do biblioteki szkolnej. Hole przed bibioteką szkolną, podobnie jak genkan, były drugim miejscem w przestrzeniach szkolnych, gdzie należało dokonać oczyszczenia.

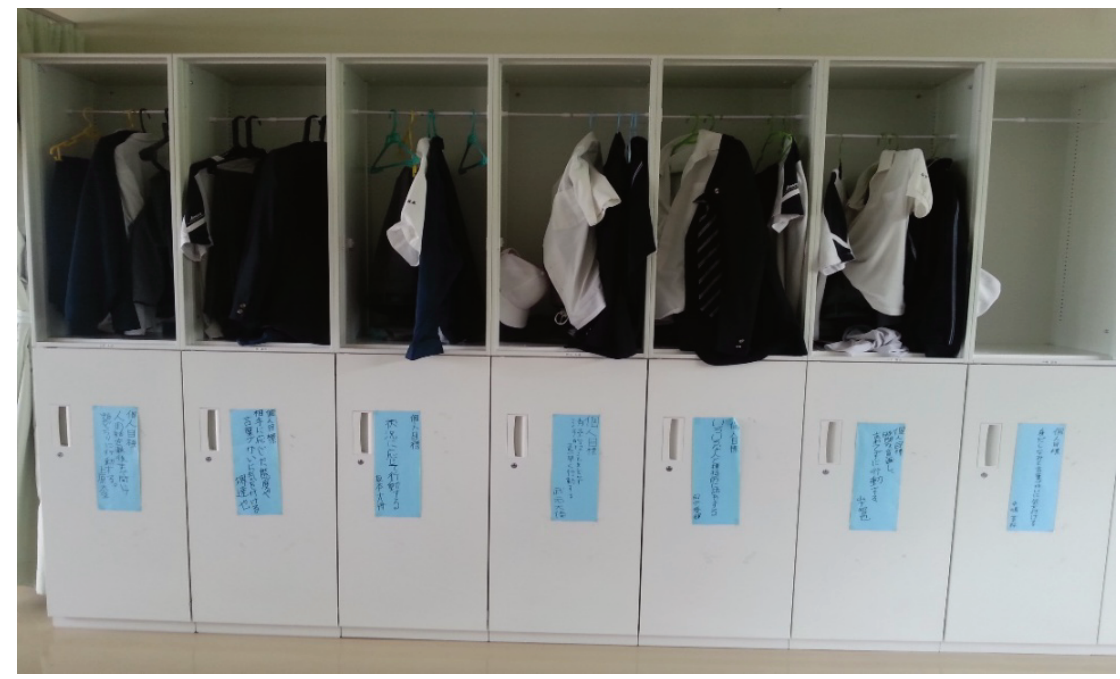

Fot. 4. Szafki w klasie lekcyjnej - tokushu gakkō (特殊学校) Źródło: archiwum prywatne B. Borowska-Beszta 


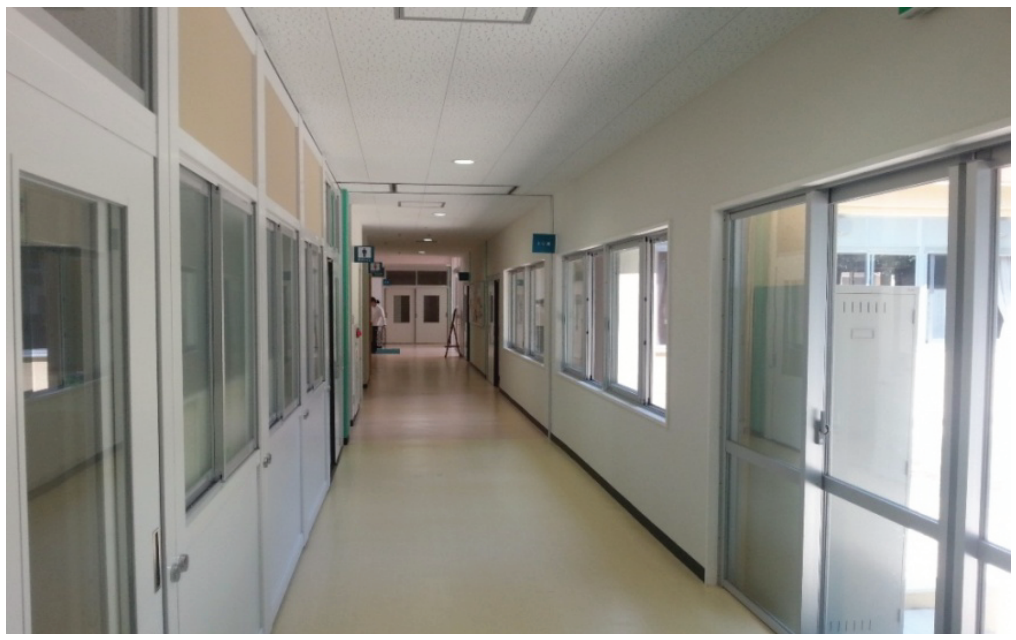

Fot. 5. Korytarz w szkole specjalnej - tokushu gakkō (特殊学校) Źródło: archiwum prywatne B. Borowska-Beszta

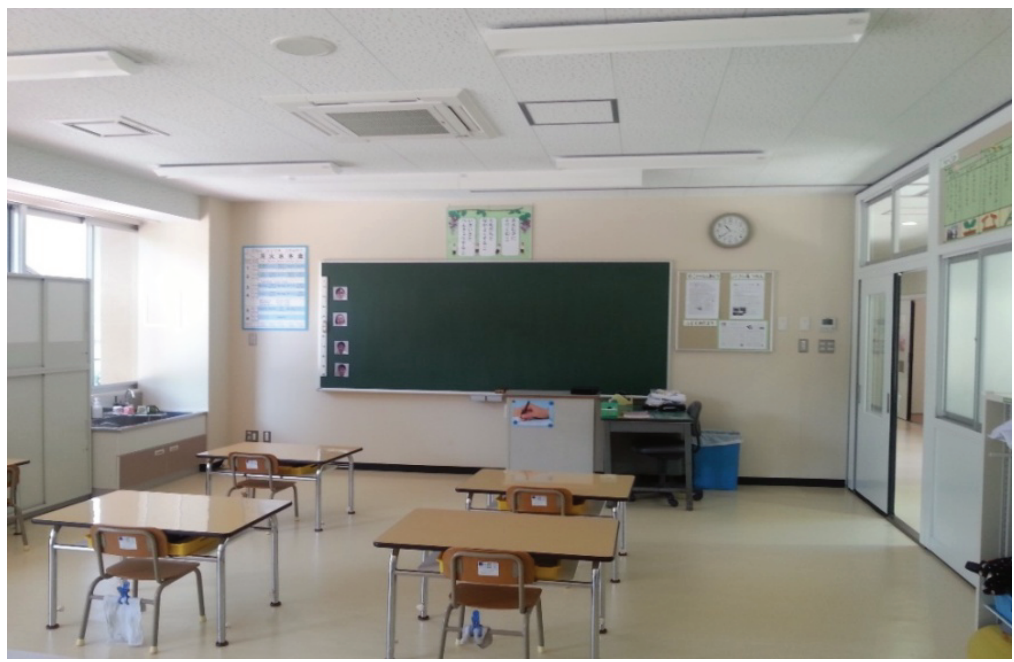

Fot. 6. Klasa szkolna - kyōshitsu (教室) w szkole specjalnej - tokushu gakkō (特殊学 校) dla dzieci z niepełnosprawnością intelektualną - chiteki shōgai (知的障害) Źródło: archiwum prywatne B. Borowska-Beszta 


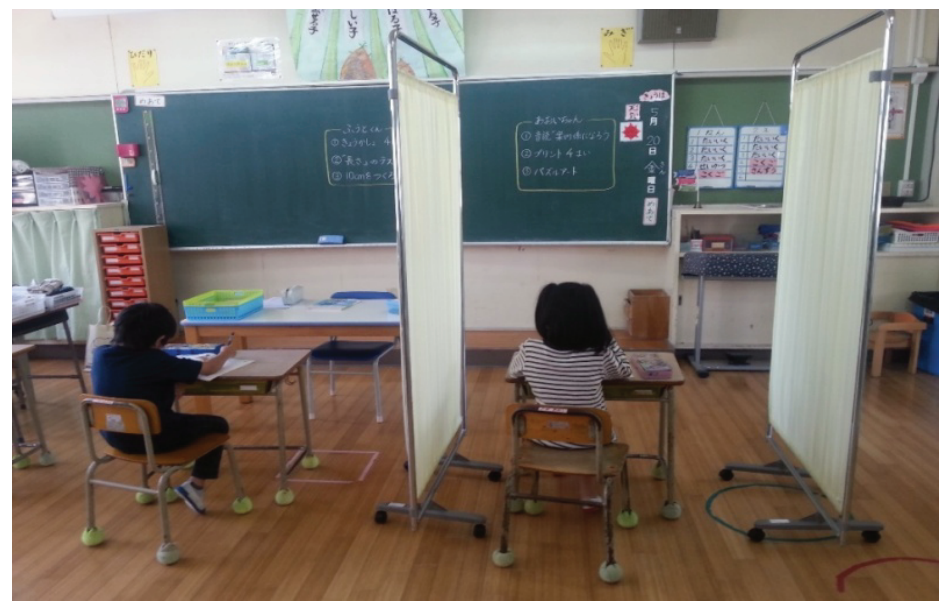

Fot. 7. Klasa szkolna - kyōshitsu (教室) w szkole ogólnodostępnej z klasami specjalnymi dla dzieci z zaburzeniami rozwoju - hattatsu shōgai (発達障) ze spektrum autyzmu Źródło: archiwum prywatne B. Borowska-Beszta

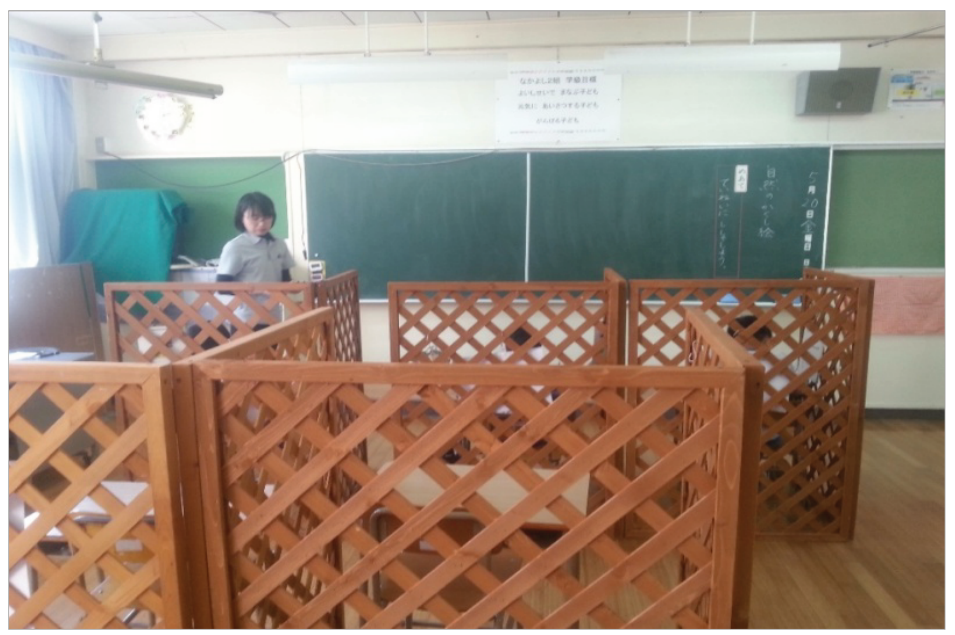

Fot. 8. Klasa szkolna - kyōshitsu (教室) w szkole szkole ogólnodostępnej z klasami specjalnymi dla dzieci z zaburzeniami rozwoju - hattatsu shōgai (発達障) ze spektrum autyzmu

Źródło: archiwum prywatne B. Borowska-Beszta 


\section{Dyskusja}

Podsumowując proces gromadzenia danych oraz analizy artefaktów fizycznych i behawioralnych, podczas badań terenowych w siedmiu placówkach edukacji specjalnej, inkluzyjnej i wsparcia dorosłych w Japonii chcę zauważyć, że kultury organizacyjne w których gromadziłam dane, cechowało uporządkowanie, harmonia przestrzeni, koncentracja i spokój. Ponadto każda placówka edukacyjna miała na terenie zespołów szkół przylegający niewielki ogród medytacji ZEN. Chcę dodać, że gromadzenie danych wizualnych okazało się przydatną techniką obserwacji uczestniczącej, gdyż gromadzenie danych werbalnych - wywiadów było niekiedy utrudnione z powodu słabej znajomości języka angielskiego wśród japońskich akademików z którymi miałam kontakt i mojego braku znajomości języka japońskiego (poza zwrotami grzecznościowymi i umiejętnością liczenia do 10). Wyjątek i pewien ewenement stanowi sam Profesor N. Tasaki oraz niektórzy dyrektorzy i nauczyciele szkół, terapeuci w placówce dla dorosłych. Myślę, że badania mogą dodać nowego wymiaru i wglądu w światowe, kulturowe studia nad niepełnosprawnością i systemy edukacji oraz wsparcia. Dodatkowo praktyka badań terenowych na gruncie Japonii była wielostronnie zaskakująca dla mnie jako Europejki. W miarę zanurzania się w edukacyjne kultury organizacyjne dostrzegałam subtelności orientalnych konceptualizacji artefaktów behawioralnych oraz niewyraźne i trudne do ustalenia granice przyporządkowania przestrzeni i artefaktów materialno-fizycznych przestrzeni systemu edukacji specjalnej i inkluzyjnej do kontinuuk ohyake, watakushi i puraibashii. Praktyka terenowa i niekiedy trudne sytuacje i wyzwania w terenie badawczym stały się momentem krytycznym do właściwego rozumienia artefaktów fizycznych i behawioralnych badanych kultur edukacyjnych $\mathrm{w}$ kategoriach tego, co jest dla Japończyków przestrzenią ohyake (公) (publiczną) i tego, co jest przestrzenią watakushi (私) i puraibashii (プライバシー) (prywatną). Badając edukacyjne kultury organizacyjne $\mathrm{w}$ Fukuoce $\mathrm{w}$ Japonii, po uprzednich 
własnych badaniach ${ }^{56}$, zauważam pewną prawidłowość polegającą na znaczącej roli odźwiernego (gate keepera) w badaniu japońskich edukacyjnych kultur organizacji. Moim zdaniem w przypadku kultur organizacyjnych edukacji specjalnej lub inkluzyjnej Japonii, bez osoby posiadającej autorytet i niekwestionowany szacunek społeczny oraz pozycję w środowisku, stanowiącym scenę kulturową badaną i wprowadzjącej badacza do badanego systemu, nawet artefakty materialno-fizyczne, nie mówiąc o behawioralnych, nie będą wcale dostępne badaczowi spoza Japonii w tej kulturze tradycyjnej, silnie zhierarchizowanej i zrytualizowanej oraz trudno dostępnej. Ujawnianie informacji przez Japończyków o problemach intersujących mnie badawczo było kwestią wielce delikatną i trudną dla nich.

\section{Konkluzje}

Analizy przestrzeni i artefaktów fizyczno-materialnych badanych kultur organizacyjnych wskazały ich silne powiązanie $\mathrm{z}$ artefaktami behawioralnymi. Dla przykładu trudno byłoby właściwie zrozumieć czytelnikom spoza kultury Japonii znaczenie procesu puryfikacji w genkan (玄関), w kulturach organizacyjnych analizowanych szkół bez jednoczesnej analizy artefaktów behawioralnych związanych z dookreślonym normami szkolnymi zachowaniem w tej przestrzeni puryfikacji. Kultury organizacyjne sześciu szkół specjalnych i szkole ogólnodostępnej z klasami inkluzyjnymi i specjalnymi różnych poziomów edukacyjnych i jednego ośrodka wsparcia dorosłych wskazują, zarówno w charakterze przestrzeni, jak i artefaktach szkolnych, projektowanie z myślą o specjalnych potrzebach edukacyjnych uczniów z niepełnosprawnościa intelektualną, zaburzeniami rozwoju oraz silne ugruntowanie w japońskich wzorach kulturowych projektowania przestrzeni w ogóle. Prowadzone analizy wskazały istnienie przestrzeni transparentnych i przy-

56 B. Borowska-Beszta, Etnografia stylu życia kultury dorostych torunian z zaburzeniami rozwoju, UMK, Toruń 2013. 
jaznych dzieciom, młodzieży ale jednocześnie bardzo przyjaznych władzy szkół. Sześć szkół i dwa uniwersytety, w których również gromadziłam dane, są bowiem otoczone murami i mają bramy elektrycznie otwierane. Korytarze szkół podstawowych i gimnazjów są w przeszklone, dające wgląd w to, co się dzieje podczas lekcji. Sześć szkół i jedna placówka wsparcia dorosłych były zaprojektowane zgodnie z potrzebami uczących się osób z niepełnosprawnością. Analizowane przestrzenie szkolne, $\mathrm{z}$ artefaktami fizycznymi i behawioralnymi odzwierciedlają moim zdaniem przestrzenie, w których manifestuje się wskazany przeze mnie w pierwszej części artykułu 9. rezerwuar kulturowego kodowania konstruktu niepełnosprawności, skoncentrowany na osobie rozwijającej się. Nastawienie na rozwój potencjału uczniów z niepełnosprawnością intelektualną było nadrzędnym celem, który wynikał z rozmów z japońskimi nauczycielami. Kluczem było zatem silne ukierunkowanie na rozwój potencjału uczniów, aby podołali dorosłemu życiu społecznemu w Japonii i jego wymaganiom. Organizacja klas szkolnych specjalnych była moim zdaniem optymalna i uczyło się w niej po czworo, pięcioro dzieci z niepełnosprawnością intelektualną $\mathrm{w}$ stopniu umiarkowanym, znacznym i zaburzeniami rozwoju. Ponadto chcę zauważyć, że artefaktem fizycznym szkoły jest (oprócz wszystkich elementów wyposażenia klas, korytarzy, które omawiałam) szczegółowo uregulowane w statutach szkół umundurowanie uczniów, jak też wymagany oficjalny ubiór nauczycieli. Oznacza to garnitur lub garsonkę, chyba że nauczyciel naucza wychowania fizycznego i nakłada odzież sportową. Umundurowanie i ubiór mają również w szkołach ukryte i zakodowane symbole. W szkole ogólnodostępnej z klasami inkluzyjnymi uczestniczyłam w przygotowaniach do tradycyjnego japońskiego festiwalu o charakterze włączającym, którego rytuał ćwiczono na boisku szkolnym. Siedzący obok mnie anglista zwrócił szeptem moją uwagę na oznaczenia dzieci i młodzieży numerami na koszulkach, na plecach. Dzieci z najwyższym potencjałem fukcjonalnym i intelektualnym, te najzdolniejsze miały oznaczenia na plecach numerem 1 , potem 2 , oraz inne 3, natomiast dzieci z niepełnosprawnościami były oznaczone 4 . Wypatrywałam zatem 4 . 
Warto dodać, że czwórka w kulturze Japonii ma specjalne znaczenie, lecz traktowana jest, niestety, jako liczba pechowa, a wymawiana jako (shi し) budzi bliskie skojarzenia ze śmiercią.

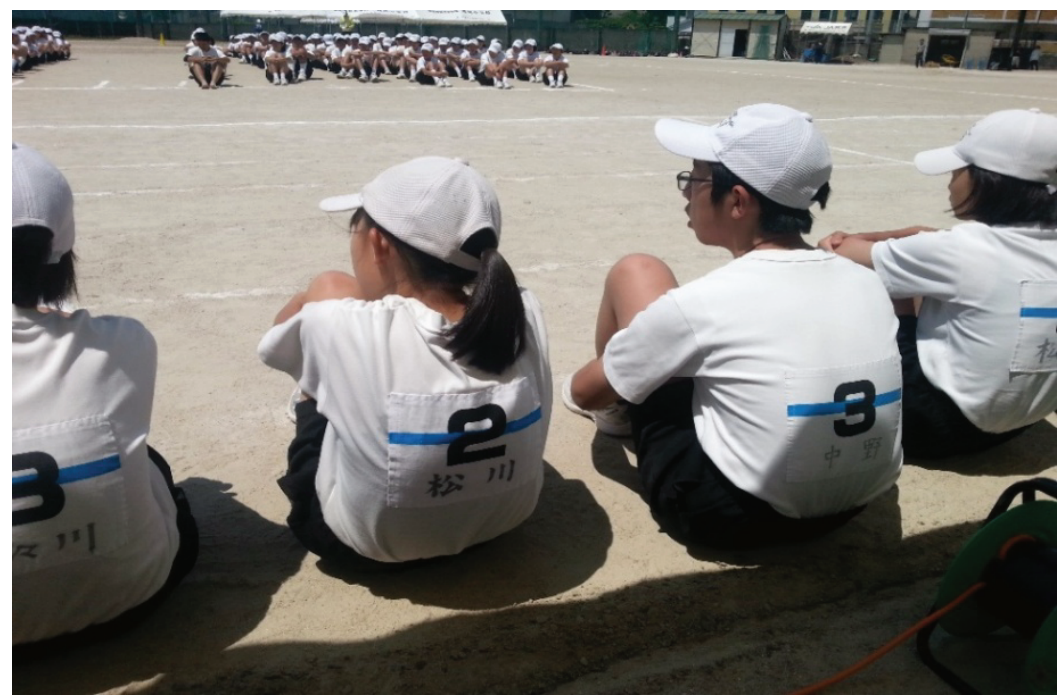

Fot. 9. Na boisku szkolnym uniwersyteckiej szkoły ogólnodostępnej z klasami inkluzyjnymi

Fot. Archiwum prywatne B. Borowska-Beszta

\section{Bibliografia}

Angrosino M., Badania etnograficzne i obserwacje, PWN, Warszawa 2010.

Banks M., Materiały wizualne w badaniach jakościowych, Niezbędnik Badacza, PWN, Warszawa 2009.

Borowska-Beszta B., Analiza antropologiczna jako transformacja: Problemy i techniki generowania tematów kulturowych, „Problemy edukacji rehabilitacji socjalizacji osób niepełnosprawnych: Wybrane zagadnienie metodologii i metodyki badań w obszarze niepełnosprawności icodzienności osób z niepełnosprawnością" 2016, Vol. 23.

Borowska-Beszta B., Anatema(?) szoku kulturowego w andragogice specjalnej, „Edukacja Otwarta" 2008, nr 2, s. 163-179. 
Borowska-Beszta B., Etnografia dla terapeutów (pedagogów specjalnych) - szkice metodologiczne, Oficyna Wydawnicza „Impuls”, Kraków 2005.

Borowska-Beszta B., Etnografia stylu życia kultury dorostych torunian z zaburzeniami rozwoju, UMK, Toruń 2013.

Borowska-Beszta B., Pracownicy Fundacji (metoda etnograficzna), [w:] Formowanie się wspólnoty w Fundacji im. Brata Alberta w Radwanowicach, Wydawnictwo i Drukarnia Towarzystwa Słowaków w Polsce, Kraków 2001, s. 260-322.

Creswell J., Research Design: Qualitative, Quantitative, and Mixed Methods Approaches. 3rd Edition. Sage Publications, Inc, Los Angeles 2009.

Denzin N., Lincoln Y., Metody badań jakościowych, T. 1, 2. PWN, Warszawa 2009.

Educational Research and Evidence-based Practice. In association with the Open University, red. M. Hammersley, Sage, London 2007.

Flick U., Projektowanie badania jakościowego, PWN, Warszawa 2010.

Gibbs G., Analizowanie danych jakościowych, PWN, Warszawa 2010.

Green J.L., Bloome D., Ethnography and ethnographers of and in education: a situated perspective, [w:] Handbook for literacy educators: research in the community and visual arts, red. J. Flood, S.B. Heaths, D. Lapp, Macmillan, New York 1997.

Hall E., Ukryty wymiar, Muza, Warszawa 1997.

Hammersley M., Atkinson P., Metody badań terenowych, Zysk i S-ka, Poznań 2000.

Hammersley M., Teaching qualitative methodology: craft, profession or bricolage, [w:] Qualitative Research Practice, red. C. Seale, G. Gobo, J.F. Gubrium, D. Silverman, Thousand Oaks, Sage 2004.

Jemielniak D., Badania jakościowe, Metody i narzędzia. T.2, PWN, Warszawa 2012.

Jemielniak D., Badania jakościowe, Podejścia i teorie. T. 1, PWN, Warszawa 2012.

Kawecki I., Dane wizualne w badaniach pedagogicznych, „Pedagogika Kultury” 2009, t. 5.

Kostera M., Antropologia organizacji, Metodologia badań terenowych, PWN, Warszawa 2003.

Kubinowski D., Jakościowe badania pedagogiczne. Filozofia - Metodyka - Ewaluacja, UMCS Lublin 2010.

Nakada M., Tamura T., Japanese Conceptions of Privacy: An Intercultural Perspective, "Ethics and Information Technology" 2005, March, 7/1.

Nalaskowski A., Przestrzenie i miejsca szkoty, Oficyna Wydawnicza „Impuls”, Kraków 2000.

Nowotniak J., Społeczne światy pokoi nauczycielskich, „Teraźniejszość - Człowiek Edukacja: kwartalnik myśli społeczno-pedagogicznej” nr 3 (55), 71-86.

Pink S., Etnografia wizualna. Obrazy, media i przedstawienie w badaniach, UJ, Kraków 2008.

Schein E.H., Organizational Culture and Leadership, Jossey-Bass, San Francisco 2010.

Schein E., Organizational Culture and Leadership. Jossey-Bass, [w:] L. Zbiegień-Maciąg, Kultura w organizacji - Identyfikacja kultur znanych firm, PWN, Warszawa 1999. 
Siarkiewicz E., Trębińska-Szumigraj E., Zielińska-Pękał D., Edukacyjne prowokacje. Wykorzystanie etnografii performatywnej w procesie kształcenia doradców, Oficyna Wydawnicza „Impuls”, Kraków 2012.

Spradley J., Participant observation. New York: Holt, Rinehart \& Winston, New York 1980.

Spradley J., The Ethnographic interview, Holt, Rinehart \& Winston, New York 1979.

Tamura T., Japanese feelings for privacy MANUSYA: Journal of Humanities (Special Issue No. 8 2004) pp. 138-156, http:/ / www.manusya.journals.chula.ac.th/files/ essay/Tamura_p121-139.pdf [dostęp: 4.07.2017].

Whitehead T.L., Basic Classical Ethnographic Research Methods Secondary Data Analysis, Fieldwork, Observation/Participant Observation and Informal and Semistructured Interviewing, 2005. http://www.cusag.umd.edu/documents/working papers/classicale thnomethods.pdf [dostęp 4.07.2017].

Wiernek B., Kultura organizacyjna przedsiębiorstwa, Oficyna Wydawnicza TEXT, Kraków 2000.

Wolcott H.F., Posturing in qualitative inquiry, [w:] The Handbook of Qualitative Research in Education, red. M.D. LeCompte, W.L. Millroy \& JPreissle, Academic Press, NewYork 1992.

Wolfensberger W., The Origin And Nature Of Our Institutional Models, [w:] Changing Patterns in Residential Services for the Mentally Retarded, President's Committee on Mental Retardation, Washington, D.C. January 1969, http://www.disabi litymuseum.org/dhm/lib/detail.html?id=1909\&page=all [dostęp: 4.07.2017]. 